\title{
PROPERTIES AND INHIBITION OF THYMIDYLATE SYNTHETASE IN DROSOPHILA MELANOGASTER*
}

\author{
NANCY J. CARPENTER \\ Department of Zoology, University of Michigan, Ann Arbor, Michigan 48104, U.S.A.†
}

(Received 19 June 1973; revised 20 December 1973)

\begin{abstract}
A quantitative comparison of the incorporation of methyl- ${ }^{3} \mathrm{H}$ thymidine and $6-^{3} \mathrm{H}$-deoxyuridine into the DNA of Drosophila melanogaster in the presence and in the absence of 5-fluorouracil indicated that 5-fluorouracil inhibits the reaction converting dUMP to dTMP catalysed by thymidylate synthetase (methylenetetrahydrofolate:dUrd-5'-P C-methyltransferase, E.C. 2.1.1.b). The enzyme exhibits maximal activity at $\mathrm{pH} 7.5$ to 8.0 and is protected from heat inactivation by deoxyuridine monophosphate. The addition of thiol compounds to the homogenization buffer results in the enhancement of synthetase activity. The $K_{m}$ values for deoxyuridine monophosphate and 5,10 -methylenetetrahydrofolate are $6.8 \times 10^{-6} \mathrm{M}$ and $8.3 \times 10^{-5} \mathrm{M}$, respectively. Fluorodeoxyuridine monophosphate, trifluoromethyldeoxyuridine monophosphate, and methotrexate are inhibitors of the enzyme. 5-Bromodeoxyuridine and 5-iododeoxyuridine have no inhibitory effect. The results support the contention that, under conditions which induce morphological lesions in Drosophila, fluorinated pyrimidines and methotrexate inhibit the de novo synthesis of thymidylate whereas thymidine analogues function in some other manner.
\end{abstract}

\section{INTRODUCTION}

The BIOSYNTHEsis of DNA in insects has been studied primarily in the silkmoths Hyalophora cecropia and Antheraea pernyi in which DNA synthesis resumes at the onset of adult development after being absent in most tissues during pupal diapause (Brookes and Williams, 1965; BerRY and FirsheIN, 1967; Firshein et al., 1967; BERRY et al., 1970; FrEEMAN et al., 1972). An extensive study of the factors controlling the temporal pattern and rate of DNA synthesis in various tissues of the Cecropia silkmoth and other Saturniid moths has been reported (KRISHNAKUMARAN et al., 1967).

The absence of DNA synthesis in diapausing pupae has suggested that one or more of the enzymes involved in the biosynthetic pathways for DNA may be inhibited. Studies on several enzymes in the pyrimidine pathways have shown

* This work was supported by N.I.H. Genetics Training Grant No. 5-T0 1 GM71-14 and by N.I.H. Grant No. CA 12600-02 to Dr. T. M. Rizki.

$\dagger$ Present address: Department of Life Sciences, University of Tulsa, Tulsa, Oklahoma 74104, U.S.A. 
that thymidine kinase and thymidylate kinase in $A$. pernyi and deoxyuridine kinase in $H$. cecropia are not correlated with the presence or absence of DNA synthesis (BROOKEs and Williams, 1965; FirsheIN et al., 1967). In contrast, the presence of thymidylate synthetase and deoxycytidine deaminase has been correlated with DNA synthesis in $H$. cecropia by the observation that the enzymes were detectable in significant amounts at the onset of pharate adult development but not in diapausing or injured diapausing pupae (FIRsheIN et al., 1967).

Studies in mammalian systems have correlated changes in the activity of thymidylate synthetase with the rates of cell division in cell culture and in normal and neoplastic cell populations in vivo (HartmanN and HeIdelberger, 1961; CoNrad, 1971). The absence of detectable levels of this enzyme in non-dividing cells (adult rat liver) has led to the suggestion that thymidylate synthetase may catalyse a rate-limiting step in thymidylate synthesis (MALEY and MALEY, 1959).

The importance of this enzyme in the de novo synthesis of DNA coupled with the availability of a wide variety of mutant strains in Drosophila has led to the study of thymidylate synthetase in this organism. The normal pattern of regulation of thymidylate synthetase throughout development of $D$. melanogaster and the activity of the enzyme in the ovaries of several mutant strains exhibiting different ovarian physiologies have been reported (CARPENTER, 1973).

The present study characterizes thymidylate synthetase in $D$. melanogaster and describes its inhibition by fluorinated pyrimidine mononucleotides and methotrexate (amethopterin). The inhibition of this enzyme is of particular interest in view of the suggestion by RizkI et al. (1972) that fluorouracil (FU) may be converted in Drosophila to an inhibitor of thymidylate synthesis and thereby facilitate the incorporation of thymidine analogues into DNA. RIzKI and RizKI (1969, 1972) have found that dietary treatment of Drosophila larvae with FU and 5bromodeoxyuridine (BUdR) or 5-iododeoxyuridine (IUdR) induces a variety of morphological lesions in the hatching adult flies which include bristle alterations and supernumerary growths.

\section{MATERIALS AND METHODS}

\section{Drosophila strain}

The Oregon- $R$ wild-type strain of $D$. melanogaster was maintained on cornmealmolasses medium at $25^{\circ} \mathrm{C}$. Larvae were grown on cream of wheat medium at $25^{\circ} \mathrm{C}$ until the appropriate ages for use.

\section{DNA studies}

For determining the incorporation of radioactive precursors, DNA was isolated according to the method of RitossA et al. (1966) from groups of $72 \pm 1 \mathrm{hr}$ larvae which had been placed on the following solutions for $8 \mathrm{hr}$; (a) thymidine, (b) thymidine +5-fluorouracil, (c) deoxyuridine, (d) deoxyuridine +5-fluorouracil. Methyl- ${ }^{3} \mathrm{H}$-thymidine (sp. act. $6.7 \mathrm{Ci} / \mathrm{m}$-mole, New England Nuclear) was added to an aqueous solution of thymidine (Sigma Chemical Co.) and 6- ${ }^{3} \mathrm{H}-$ deoxyuridine (sp. act. $13 \mathrm{Ci} / \mathrm{m}$-mole, New England Nuclear) was added to a 
solution of uridine (Calbiochem) giving final concentrations of $0.20 \mathrm{mg} / \mathrm{ml}$. In the solutions containing 5-fluorouracil (Hoffman-LaRoche), the concentration of the analogue was $0.15 \mathrm{mg} / \mathrm{ml}$. The radioactivity of the solutions in the containers was determined at the beginning of the treatment period. The concentration of the DNA samples was determined by the method of BuRToN (1956) using purified calf thymus DNA as a standard. Scintillation fluid containing $0.4 \% \mathrm{PPO}, 0.005 \%$ dimethyl POPOP, BBS-2, and BBS-3 (Beckman Instrument Co.) in toluene was used for counting aliquots of the DNA samples in a Nuclear Chicago Unilux I scintillation counter. The radioactivity of each sample was based on triplicate determinations each counted for a total of $10 \mathrm{~min}$.

\section{Preparation of the enzyme}

The enzyme was prepared from larvae $72 \pm 1 \mathrm{hr}$ of age which had been placed on paper pulp saturated with distilled water for 1 to $2 \mathrm{hr}$ to eliminate yeast from the gut. The extraction procedure has been described previously (CARPENTER, 1973). Protein concentration was measured by the method of LowRY et al. (1951) with crystalline bovine albumin as a standard.

\section{Enzyme assay}

Thymidylate synthetase activity was measured by determining the obligatory release of tritium from ${ }^{5-} \mathrm{H}-\mathrm{dUMP}$ into water upon its conversion to dTMP by the method of LOMAX and GrERNBERG (1967) with the modifications developed by KAMMEN (1966). An assay mixture including the necessary requirements for the reaction except $5-{ }^{3} \mathrm{H}-\mathrm{dUMP}$ contained $0.2 \mathrm{M}$ Tris-chloride, $\mathrm{pH} 7 \cdot 5,0 \cdot 1 \mathrm{M}$ $\mathrm{MgCl}_{2}, 0.06 \mathrm{M}$ formaldehyde, $0.4 \mathrm{M}$ 2-mercaptoethanol, $4 \mathrm{mM}$ EDTA, and 0.705 to $1.36 \mathrm{mg} / \mathrm{ml}$ DL-tetrahydrofolate (General Biochemicals). The reaction was initiated by the addition of $0.01 \mathrm{ml}$ of $5-{ }^{-3} \mathrm{H}$-dUMP ( 4 nmoles, $2-6 \times 10^{6}$ counts/ min per $\mu$ mole, Calbiochem) to a reaction mixture containing $0.02 \mathrm{ml}$ of the assay mixture and $0.05 \mathrm{ml}$ of the enzyme preparation for a final volume of $0.08 \mathrm{ml}$. Details of the assay procedure have been published (CARPENTER, 1973). The specific activity is given in terms of $\mu$ natoms of tritium released in $30 \mathrm{~min}$ per $\mathrm{mg}$ protein at $25^{\circ} \mathrm{C}, \mathrm{pH} 7 \cdot 5$.

\section{Inhibition studies}

The activity of thymidylate synthetase was determined in enzyme preparations from homogenates of larvae which had been placed in small Petri dishes on Whatman paper pulp saturated with aqueous solutions of the compounds being tested for inhibition from 66 to $72 \pm 1 \mathrm{hr}$ of age. Control larvae were placed on distilled water.

In the experiments which investigated the in vitro inhibition of the enzyme by fluorinated pymidines, thymidine analogues, and methotrexate, the reaction mixtures contained $0.01 \mathrm{ml}$ of these compounds in a final volume of $0.09 \mathrm{ml}$. A 10 min preincubation of the inhibitor solution with the enzyme preparation was employed in some cases. When ATP was used, the final concentration was $2 \mathrm{mM}$. 
In the control tubes, distilled water was substituted for the inhibitor and/or ATP. BUdR and IUdR were obtained from Calbiochem and methotrexate was from American Cyanimid Co.

\section{RESULTS}

\section{Incorporation of thymidylate precursors into $D N A$}

In order to assess whether FU has an effect on thymidylate synthesis in Drosophila, a quantitative comparison of the incorporation of ${ }^{3} \mathrm{H}$-labelled thymidine and 6- ${ }^{3} \mathrm{H}$-deoxyuridine into DNA was made in the presence and in the absence of FU. As summarized in Table 1 , there was an increased incorporation of methyl- ${ }^{3} \mathrm{H}-$ thymidine and a reduced incorporation of $6-{ }^{3} \mathrm{H}$-deoxyuridine into DNA in the presence of FU. The data indicated that FU inhibited the synthesis of thymidylate at the step converting dUMP to dTMP thus facilitating the incorporation of exogenous thymidine into DNA.

\section{Properties of the enzyme}

The enzyme catalysing this conversion, thymidylate synthetase, was investigated in extracts from $72 \pm 1 \mathrm{hr}$ larvae. Under the usual assay conditions, the release of tritium was proportional to the time of incubation for $30 \mathrm{~min}$ and to the amount of protein added to approximately $100 \mu \mathrm{g}$. The optimal incubation temperature was $25^{\circ} \mathrm{C}$. From an Arrhenius plot (not shown) the energy of activation was calculated to be $19.1 \mathrm{kcal} / \mathrm{mole}$.

Incubation of the enzyme preparation at $55^{\circ} \mathrm{C}$ for $10 \mathrm{~min}$ resulted in almost complete loss of activity but in the presence of dUMP $(1 \mathrm{mM})$ the synthetase was protected against heat inactivation (Fig. 1). After preincubation at $55^{\circ} \mathrm{C}$ with $1 \mathrm{mM}$ dUMP, 82 per cent of the enzyme activity remained.

The thiol compounds, dithiothreitol and 2-mercaptoethanol, enhanced the enzyme activity, up to 126 per cent with $10 \mathrm{mM}$ dithiothreitol and by 62 per cent with $10 \mathrm{mM}$ 2-mercaptoethanol, when included in the homogenizing buffer. Since 2-mercaptoethanol was also present in the assay mixture, it appears that the thiol compounds were necessary for maximal synthetase activity apart from their role in protecting tetrahydrofolate from oxidation.

The enzyme was stable to freezing and thawing but lost about 60 per cent of its activity upon storage in buffer containing 2-mercaptoethanol at $-20^{\circ} \mathrm{C}$ for 3 weeks. Dunlap et al. (1971) have suggested that such a loss in activity may be due to the formation of 2 -hydroxyethyl disulphide, the disulphide of mercaptoethanol, which they found to inhibit synthetase activity in vitro.

When assayed in $0.01 \mathrm{M}$ phosphate buffer ( $\mathrm{pH} \mathrm{6.0-7.0)}$ ) and $0.01 \mathrm{M}$ Tris-

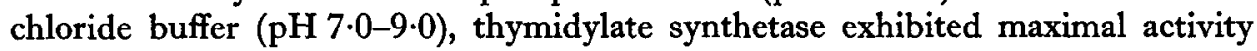
between $\mathrm{pH} 7.5$ and 8.0 .

The Michaelis constants for dUMP and 5,10-methylene- $\mathrm{FH}_{4}$ were determined from the Lineweaver-Burk plots in Fig. 2 to be $6.8 \times 10^{-6} \mathrm{M}$ and $8.3 \times 10^{-5} \mathrm{M}$, 
THYMIDYLATE SYNTHETASE IN DROSOPHILA

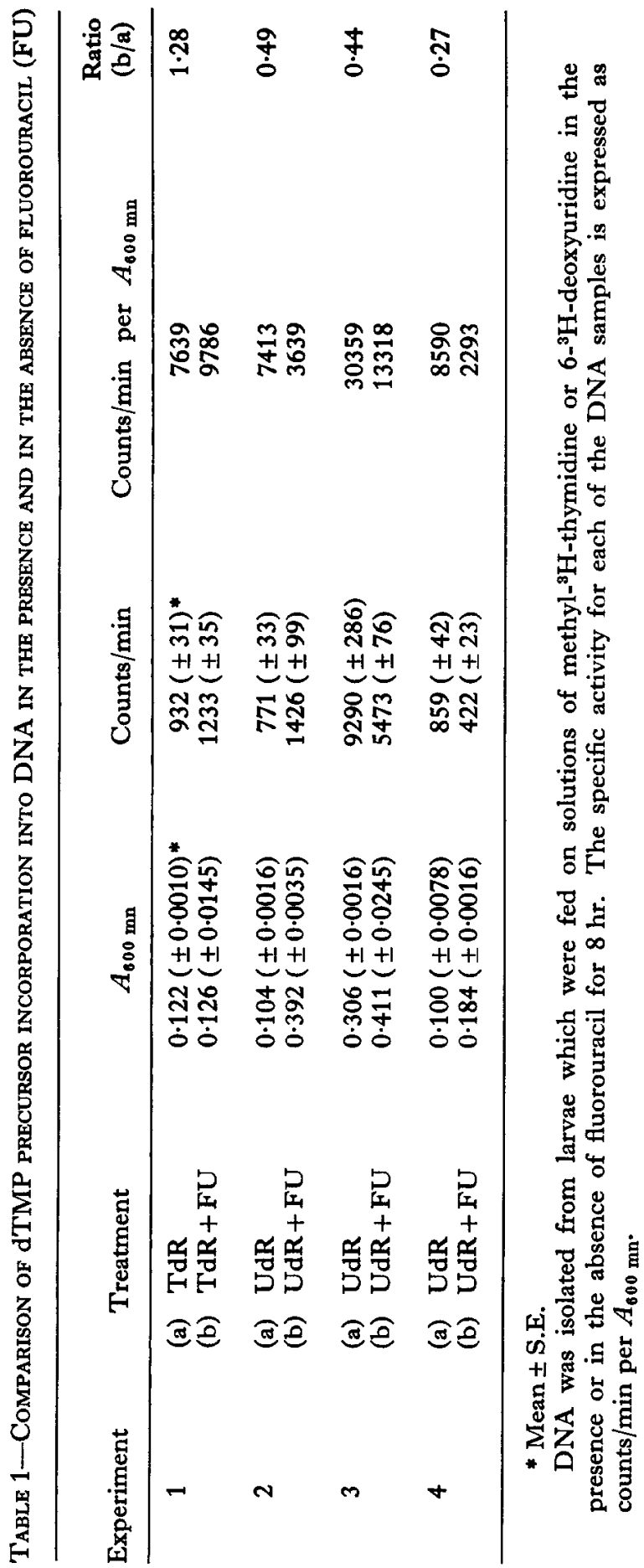


respectively. The latter value was corrected for the fact that 5,10-methylene- $\mathrm{FH}_{4}$ is a racemic mixture although only the $1, \mathrm{~L}$-diastereoisomer is active.

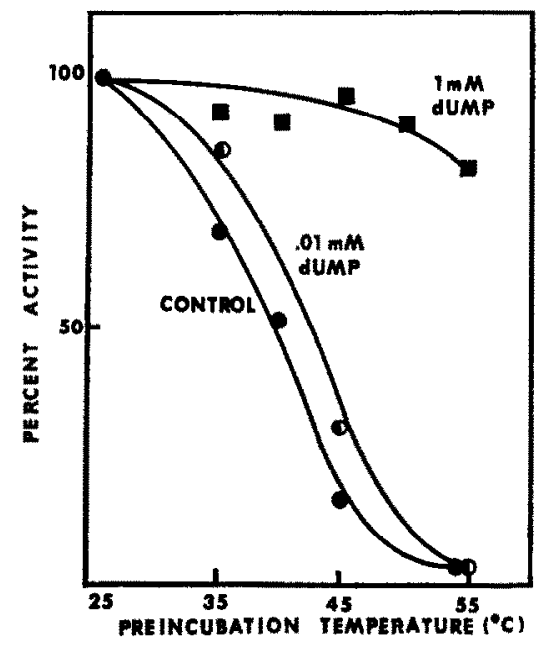

Fig. 1. The heat stability of thymidylate synthetase in the presence and in the absence of dUMP. The enzyme was preincubated for $10 \mathrm{~min}$ at the temperatures indicated in the presence of dUMP and in the absence of dUMP. The assay tubes were then place on ice during the addition of the standard assay mixture and $5-{ }^{8} \mathrm{H}$-dUMP. Incubation followed at $25^{\circ} \mathrm{C}$ for $30 \mathrm{~min}$.

\section{Inhibition of the enzyme}

The activity of the enzyme in preparations from third instar larvae fed 5fluorouracil for a $6 \mathrm{hr}$ period was lower than that of larvae placed on distilled water for a similar period. Similar results were found using trifluoromethyldeoxyuridine, a fluorinated pyrimidine, and methotrexate, a folic acid analogue, which have also been found to enhance the induction of morphological lesions in Drosophila (RIzKI and RizkI, 1973; R. M. RizkI, personal communication). The data in Table 2 indicate that an increase in the percentage inhibition of the enzyme activity corresponds to the increased concentrations of each of these compounds but that inhibition is not complete at the highest concentration used. Experiments in which increasing numbers of larvae were placed on FU solutions indicating that crowding had no effect on the ingestion of the analogue. Fluorinated pyrimidines and methotrexate have a variety of effects on cell metabolism (BLAKLEY, 1969) so further clarification of the mechanisms by which these compounds inhibit synthetase activity was necessary.

${ }^{3} \mathrm{H}$-labelled FU has been shown to be incorporated into Drosophila RNA (RIzkI, 1968). FU may therefore affect synthetase activity either by (a) the incorporation as a uracil analogue in RNA leading to inaccurate translation of the enzyme or by (b) the direct inhibition of the enzyme by FU or by a related compound. These alternatives were resolved by an experiment in which the proteinfree extract from larvae fed FU was found to decrease the synthetase activity 

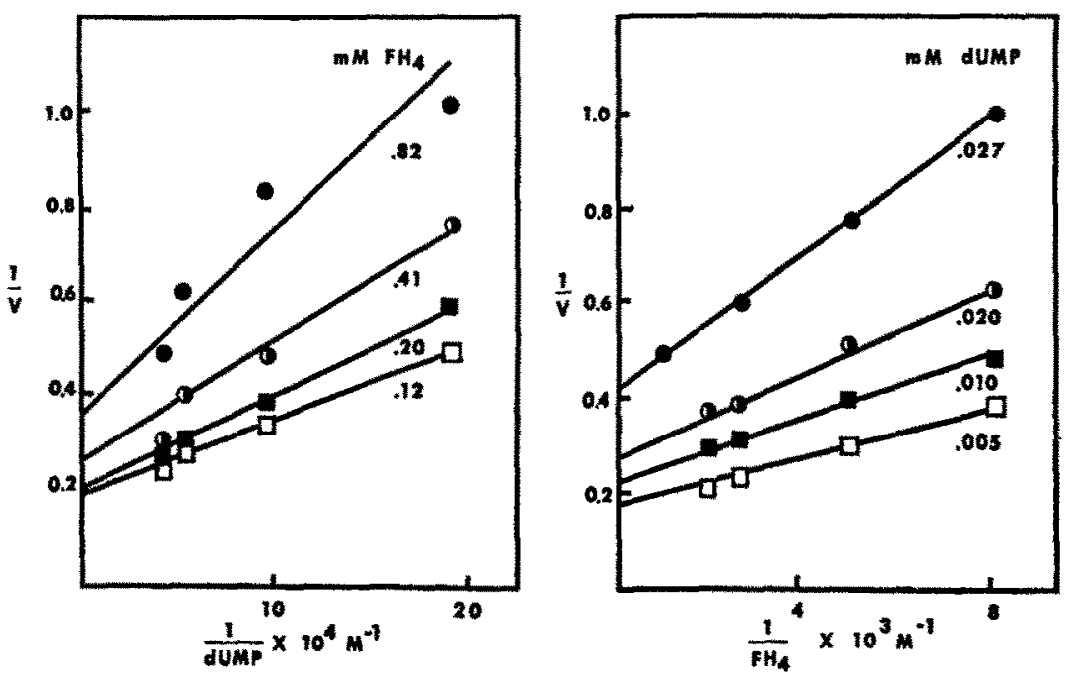

FIG. 2. The Lineweaver-Burk plots for thymidylate synthetase with dUMP or 5,10-methylene-FH, as the variable substrate. The plots are derived from an experiment in which the initial velocity was determined with four concentrations of dUMP $(0.005,0.010,0.020$, and $0.027 \mathrm{mM})$ at each of four concentrations of 5,10 -methylene-FHa $(0.12,0.20,0.41$, and $0.82 \mathrm{mM})$. The other assay components were the same as described for the standard assay.

TABLE 2-EFFEcT OF DIETARY FU, FatdR, AND MTX ON dTMP sYNTHETASE ACTrviTy in vivo

\begin{tabular}{lcccccc}
\hline & \multicolumn{6}{c}{ Per cent inhibition } \\
\cline { 2 - 6 } Treatment & $\begin{array}{c}0.0075 \\
\mathrm{mg} / \mathrm{ml}\end{array}$ & $\begin{array}{c}0.15 \\
\mathrm{mg} / \mathrm{ml}\end{array}$ & $\begin{array}{c}0.19 \\
\mathrm{mg} / \mathrm{ml}\end{array}$ & $\begin{array}{c}0.30 \\
\mathrm{mg} / \mathrm{ml}\end{array}$ & $\begin{array}{c}0.34 \\
\mathrm{mg} / \mathrm{ml}\end{array}$ \\
\hline FU & 59.0 & $67.5^{*}$ & - & 80.5 & - \\
F $T d R$ & - & - & 11.7 & - & $57.0^{*}$ \\
MTX & - & 53.7 & - & - & - \\
\hline
\end{tabular}

* Equimolar concentrations.

Approximately 100 to 200 third instar larvae were fed on $\mathrm{H}_{2} \mathrm{O}$ or solutions of FU, $F_{3} T d R$, or MTX for $6 \mathrm{hr}$.

in vitro (Table 3). The extracts from larvae fed $\mathrm{H}_{2} \mathrm{O}$ increased the activity of the enzyme probably due to the presence of endogenous substrates in the extract. In the case of the undiluted extract from larvae fed $\mathrm{FU}$, the enzyme activity was inhibited. It was possible to dilute out the inhibitor as indicated by increased activity in the presence of the diluted FU extract. After dialysis the values for enzyme activity approached the control value (100 per cent) indicating the removal of an inhibitor in the FU extract and of small molecules contributing to increased activity in the $\mathrm{H}_{2} \mathrm{O}$ extracts. 
TABLE 3-EFFECT OF LARVAL EXTRACTS ON dTMP SYNTHETASE ACTIVITY

\begin{tabular}{llcc}
\hline & & \multicolumn{2}{c}{ Per cent control activity } \\
\cline { 3 - 4 } Addition to assay & $\begin{array}{c}\text { Undialysed } \\
\text { extract }\end{array}$ & $\begin{array}{c}\text { Dialysed } \\
\text { extract }\end{array}$ \\
\hline (a) & Protein-free extract from larvae fed $\mathrm{H}_{2} \mathrm{O}$ & 194.3 & 113.6 \\
(b) & Same as (a) diluted 1: 1 with buffer & 185.5 & 109.5 \\
(c) & Protein-free extract from larvae fed FU & 88.6 & 92.2 \\
(d) & Same as (c) diluted 1 : 1 with buffer & 157.5 & 104.8 \\
\hline
\end{tabular}

Protein-free extracts $(0.04 \mathrm{ml})$ from third instar larvae fed on $\mathrm{H}_{2} \mathrm{O}$ or FU $(0.15 \mathrm{mg} / \mathrm{ml})$ for $6 \mathrm{hr}$ were added to incubation mixtures containing assay mixture, $5-{ }^{3} \mathrm{H}-\mathrm{dUMP}$, and untreated larvae extracts in a final volume of $0.12 \mathrm{ml}$. Portions of each extract were dialysed against Tris-chloride buffer ( $\mathrm{pH} 7 \cdot 5$ ) before addition to the assay. Control tubes contained $0.04 \mathrm{ml}$ of distilled $\mathrm{H}_{2} \mathrm{O}$ in place of the protein-free extracts.

TABLE 4-EFFECT OF ANALOgUES ON dTMP sYNTHETASE ACTIVITY in vitro

\begin{tabular}{|c|c|c|c|c|c|c|c|}
\hline \multirow[b]{2}{*}{ Compound } & \multirow[b]{2}{*}{$\begin{array}{c}\text { Prior } \\
\text { incubation }\end{array}$} & \multirow[b]{2}{*}{ ATP } & \multicolumn{5}{|c|}{ Per cent inhibition } \\
\hline & & & $\begin{array}{c}10^{-4} \\
M\end{array}$ & $\begin{array}{c}10^{-5} \\
M\end{array}$ & $\begin{array}{c}10^{-6} \\
\mathrm{M}\end{array}$ & $\begin{array}{c}10^{-7} \\
\mathrm{M}\end{array}$ & $\begin{array}{c}10^{-8} \\
M\end{array}$ \\
\hline FU & - & - & 0.0 & $13 \cdot 0$ & $7 \cdot 3$ & & \\
\hline \multirow[t]{4}{*}{ FUdR } & - & - & & $14 \cdot 8$ & 20.5 & $19 \cdot 6$ & \\
\hline & + & - & & $59 \cdot 0$ & $40 \cdot 2$ & $7 \cdot 9$ & 0.0 \\
\hline & - & + & & $88 \cdot 2$ & $75 \cdot 1$ & $20 \cdot 7$ & $6 \cdot 6$ \\
\hline & + & + & & $92 \cdot 5$ & $91 \cdot 4$ & $77 \cdot 6$ & $5 \cdot 3$ \\
\hline FdUMP & - & - & & & $67 \cdot 3$ & $69 \cdot 8$ & $19 \cdot 7$ \\
\hline \multirow[t]{4}{*}{$F_{8} T d R$} & - & - & $5 \cdot 2$ & $0 \cdot 8$ & & & \\
\hline & + & - & $16 \cdot 2$ & $6 \cdot 7$ & & & \\
\hline & - & + & 28.0 & $27 \cdot 3$ & & & \\
\hline & + & + & $36 \cdot 3$ & $29 \cdot 1$ & & & \\
\hline MTX & - & - & 44.8 & $30 \cdot 3$ & & & \\
\hline \multirow[t]{2}{*}{ BUdR } & - & - & $6 \cdot 3$ & $9 \cdot 3$ & & & \\
\hline & - & + & 0.0 & 0.0 & & & \\
\hline \multirow[t]{2}{*}{ IUdR } & - & - & $5 \cdot 7$ & 0.0 & & & \\
\hline & - & + & $3 \cdot 1$ & $17 \cdot 8$ & & & \\
\hline
\end{tabular}

Incubation mixtures contained $0.01 \mathrm{ml}$ of the compound to be tested and assay mixture, $5-{ }^{3} \mathrm{H}-\mathrm{dUMP}$, and enzyme in a final volume of $0.09 \mathrm{ml}$. In some cases, the compound in the presence or in the absence of ATP was preincubated for $10 \mathrm{~min}$ with the enzyme. 
FU and the corresponding nucleoside and nucleotide, FUdR and FdUMP, were examined for their effects on the synthetase activity in vitro. The results in Table 4 show that FU and FUdR minus ATP did not inhibit the synthetase activity except when FUdR was preincubated with the enzyme preparation.
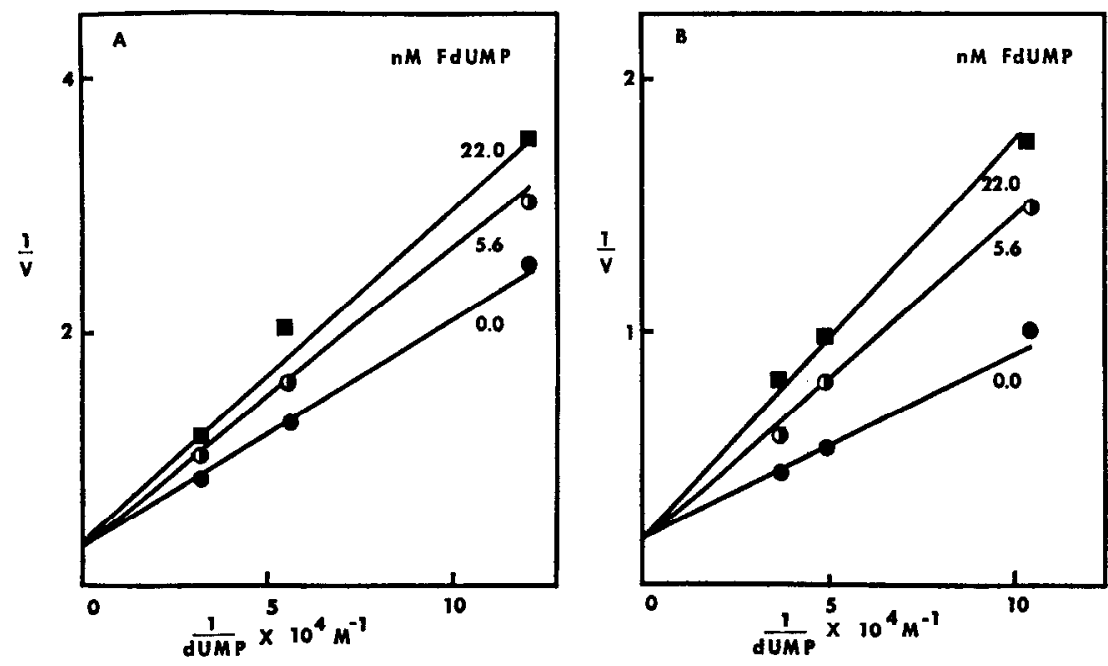

Frg. 3. The Lineweaver-Burk plots for the inhibition of thymidylate synthetase by FdUMP with respect to dUMP. (A) dUMP and FdUMP were mixed and added after a $10 \mathrm{~min}$ preincubation of all other components. (B) dUMP was added after a 10 min preincubation of FdUMP with the other assay components. FdUMP (0.01 ml) at the indicated concentrations was employed to bring the final volume to $0.09 \mathrm{ml}$. All other assay components were the same as the standard assay.

The fact that FUdR + ATP produced a marked inhibition with and without preincubation suggested that the nucleotide, FdUMP, was the actual enzyme inhibitor. Indeed, FdUMP was inhibitory at a concentration of $10^{-8} \mathrm{M}$ without prior incubation with the enzyme.

A study of the inhibition kinetics indicated that FdUMP inhibited the enzyme competitively with respect to dUMP when incubated with the enzyme preparation prior to the addition of dUMP as well as when no prior incubation was used. Lineweaver-Burk plots for these two conditions are illustrated in Fig. 3. The $K_{i, \text { slope }}$ for FdUMP decreased from a value of $3.9 \times 10^{-8} \mathrm{M}$ to $2.0 \times 10^{-9} \mathrm{M}$ upon preincubation. FdUMP uncompetitively inhibited the enzyme with respect to 5,10-methylene-FH ${ }_{4}$ (Fig. 4). A $K_{i \text {,intercept }}$ value for FdUMP of $3.15 \times 10^{-8} \mathrm{M}$ was obtained. An Ackermann-Potter plot (not shown) of enzyme activity vs. the amount of protein added resulted in a series of non-parallel lines intercepting the abscissa at zero, indicating that the inhibition by FdUMP was not stoichiometric but reversible. 


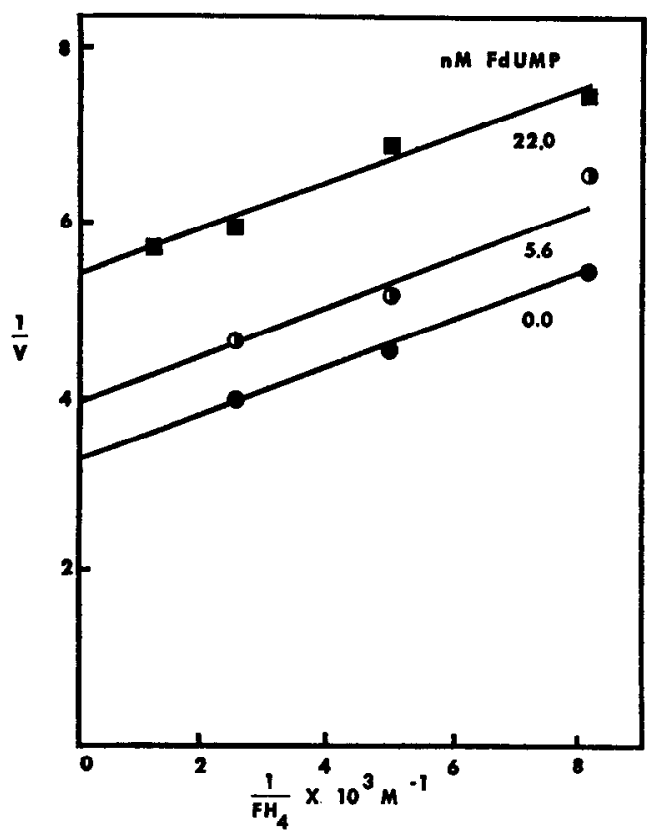

FIg. 4. The Lineweaver-Burk plot for the inhibition of thymidylate synthetase by FdUMP with respect to 5,10 -methylene- $\mathrm{FH}_{4}$. dUMP was added after a $10 \mathrm{~min}$ preincubation of FdUMP with the other assay components. The assay was the same as that described in Fig. 3.

The data for the in vitro incubation of trifluoromethyldeoxyuridine and methotrexate with the enzyme are also given in Table 4. The fact that $F_{3} T d R$ inhibited synthetase activity only in the presence of ATP was interpreted as indicating that the corresponding nucleotide, trifluoromethyldeoxyuridine monophosphate, was the actual inhibitor. MTX also inhibited the enzyme in vitro at concentrations of 5,10-methylene- $\mathrm{FH}_{4}$ which were not limiting in the reaction. The kinetics of the inhibition indicated that MTX was not competitive with respect to either dUMP or 5,10-methylene- $\mathrm{FH}_{4}$ (Fig. 5).

Since the dietary administration of BUdR and IUdR in combination with FU has been shown to induce morphological lesions, it was of interest to know the effect of these compounds on the synthetase activity in vitro. The data in Table 4 indicate that neither BUdR nor IUdR inhibited the enzyme in the presence or in the absence of ATP.

\section{DISCUSSION}

Thymidylate synthetase has been characterized in $D$. melanogaster and its properties are similar to those of the enzyme from bacterial, avian, and mammalian sources. LORENSON et al. (1967) have reported a similar activation energy as well 

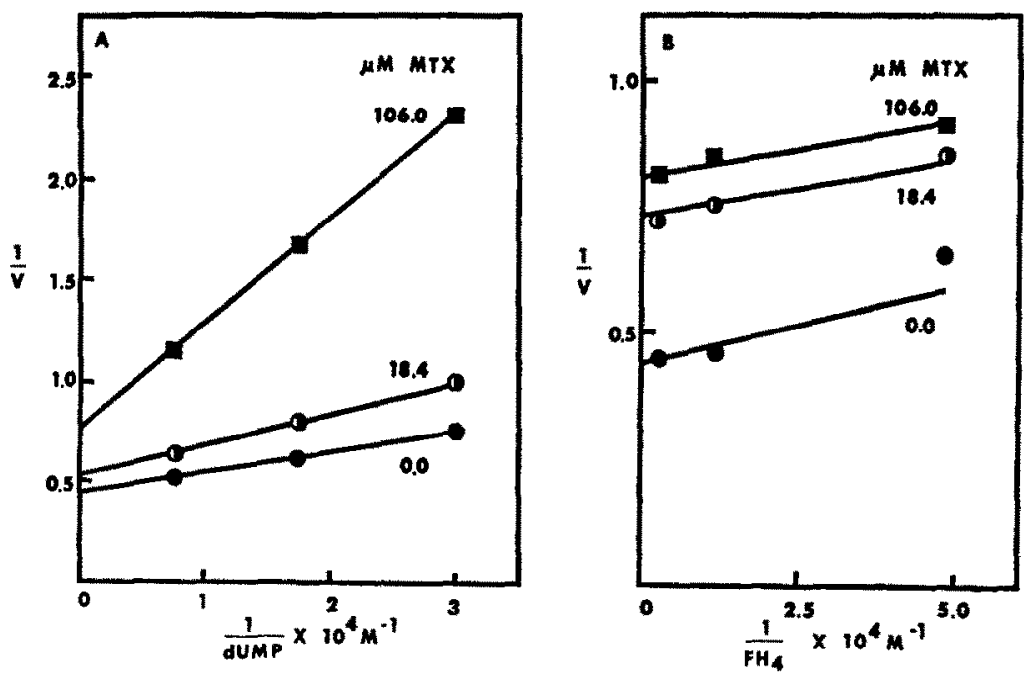

FIG. 5. The Lineweaver-Burk plots for the inhibition of thymidylate synthetase by methotrexate (MTX) with respect to dUMP and 5,10-methylene-FH. . MTX $^{\text {. }}$ $(0.01 \mathrm{ml})$ at the indicated concentrations was added without preincubation to the assay. (A) The concentration of 5,10 -methylene-FH, was $0.76 \mathrm{mM}$. The reactions were initiated by the addition of $5-{ }^{8} \mathrm{H}-\mathrm{dUMP}(0.034,0.058$, or 0.134 $\mathrm{mM}$ ). (B) The concentrations of 5,10-methylene-FH, were $0.020,0.087$, and $0.362 \mathrm{mM}$. 5 - ${ }^{3} \mathrm{H}-\mathrm{dUMP}(0.075 \mathrm{mM})$ initiated the reaction.

as the protection of the enzyme against heat inactivation by dUMP for the chick embryo synthetase. The pH optima for the bacterial synthetases (BLAKLEY, 1963) are somewhat closer to the values for the Drosophila enzyme than are those for the mammalian or chick enzyme (REYES and HeIDELBERGER, 1965; LORENSON et al., 1967). A similar enhancement of enzyme activity by thiols including dithiothreitol, 2-mercaptoethanol, glutathione, and cysteine has been found for the synthetases from various sources (DUNLAP et al., 1971). The Michaelis constants for dUMP and 5,10-methylene- $\mathrm{FH}_{4}$ are in agreement with $K_{\mathrm{m}}$ values reported for other thymidylate synthetases.

Thymidylate synthetase activity was reduced in larvae fed FU and protein-free extracts from these larvae contained a dialysable inhibitor of the enzyme. In vitro experiments established FdUMP as the actual inhibitor of the enzyme. It seems reasonable to conclude that following ingestion by the larvae, FU or FUdR are converted intracellularly to FdUMP which, in turn, inhibits the enzyme. The inhibition by FUdR minus ATP following preincubation in vitro indicates the presence in the enzyme preparation of a kinase capable of converting FUdR to FdUMP. A similar intracellular phosphorylation of $F_{3} T d R$ is also postulated. The fact that the monophosphate nucleotides corresponding to FUdR and $\mathrm{F}_{3} \mathrm{TdR}$ inhibited the enzyme in vitro is consistent with the knowledge that the reaction catalysed by the enzyme occurs at the nucleotide level. 
FdUMP competitively inhibited the enzyme with respect to dUMP in cases with and without preincubation. REYES and HEIDELBERGER (1965) reported similar inhibition kinetics for the ascites tumor synthetase. However, non-competitive inhibition following preincubation has been reported for the enzyme from chick embryo, Streptococcus faecium and phage-infected Escherichia coli (Blaklex, 1963; MATHEWs and COHEN, 1963; LORENSON et al., 1967).

Williams (1965) reported that injected fluorodeoxyuridine did not affect the survival of diapausing Cecropia pupae but blocked the termination of diapause and resulted in the cessation of development in pharate adults. These results point out the intimate relationship of the activity of thymidylate synthetase in de novo DNA synthesis to the onset of adult development.

Methotrexate has been established as an inhibitor of dihydrofolate reductase and its effect on thymidylate synthetase has generally been attributed to the limitation of 5,10-methylene- $\mathrm{FH}_{4}$. However, BorSA and WHITMORE (1969) have reported the inhibition by MTX of the synthetases from bacterial and mammalian sources. In the present study, MTX inhibited the Drosophila enzyme in the presence of excess 5,10-methylene- $\mathrm{FH}_{4}$.

In view of the observations that $F U, F_{3} T d R$, and MTX enhance the induction of morphological lesions by BUdR and IUdR, the question was raised as to the manner in which these compounds function in Drosophila. Although the effect of the fluorinated pyrimidines and MTX on the metabolism of the organism surely is not limited to the inhibition of thymidylate synthetase, the results of this study are consistent with the contention that these compounds produce a thymidylate deficiency by inhibiting this enzyme and that BUdR and IUdR do not function in this manner.

Acknowledgements-I thank Dr. T. M. RIzKI for his invaluable advice, encouragement, and support. I also acknowledge Dr. G. R. GREENBERG for a critical review of the enzyme assay system used in the present study and for the gift of 5-fluorodeoxyuridine and 5fluorodeoxyuridine monophosphate.

\section{REFERENCES}

BerRy S. J. and FIrsheIN W. (1967) Deoxynucleoside and deoxynucleotide metabolism during diapause and adult development of the Cecropia silkmoth. F. exp. Zool. 166, 1-10.

Berry S. J., Firshein W., and Swindlehurst M. (1970) The biosynthesis of DNA by insects-II. The origin of thymidylic acid during adult development of the Cecropia silkworm. Biochim. biophys. Acta 199, 1-7.

Blakley R. L. (1963) The biosynthesis of thymidylic acid-IV. Further studies on thymidylate synthetase. $\%$. biol. Chem. 238, 2113-2118.

Blakley R. L. (1969) The Biochemistry of Folic Acid and Related Pteridines. North Holland, Amsterdam.

BonsA J. and WhITMORE G. F. (1969) Studies relating to the mode of action of methotrexate-11I. Inhibition of thymidylate synthetase in tissue culture cells and in cellfree systems. Mol. Pharmacol. 5, 318-332.

Brookes V. J. and Williams C. M. (1965) Thymidine kinase and thymidylate kinase in relation to the endocrine control of insect diapause and development. Proc. nat, Acad. Sci. U.S.A. 53, 770-777. 
Burton K. (1956) A study of conditions and mechanisms of the diphenylamine reaction for the colorimetric estimation of DNA. Biochem. F. 62, 315-323.

CARPENTER N. J. (1973) Thymidylate synthetase in mutants of Drosophila melanogaster. Genetics 75, 113-122.

CoNRAD A. H. (1971) Thymidylate synthetase activity in cultured mammalian cells. $\mathcal{F}$. biol. Chem. 246, 1318-1323.

Dunlap R. B., Harding N. G. L., and HuEnNEkens F. M. (1971) Thymidylate synthetase from amethopterin-resistant Lactobacillus casei. Biochemistry 10, 88-97.

Firshein W., Berry S. J., and Swindlehurst M. (1967) The biosynthesis of DNA by insects-I. The utilization of deoxycytidine by developing adults of the Cecropia silkworm. Biochim. biophys. Acta 149, 190-198.

Freeman L. S., Swindlenurst M., and BerRy S. J. (1972) The biosynthesis of DNA by insects-IV. Metabolism of purine deoxyribonucleosides during adult development of the Cecropia silkmoth. Biochim. biophys. Acta 269, 205-209.

HartmanN K.-U. and Heidelberger C. (1961) Studies on fluorinated pyrimidines-XIII. Inhibition of thymidylate synthetase. F. biol. Chem. 236, 3006-3013.

Heidelberger C. (1965) Fluorinated pyrimidines. In Progress in Nucleic Acid Research (Ed. by Davidson J. N. and Cohn W. E.) 4, 1-50. Academic Press, New York.

Kammen H. O. (1966) A rapid assay for thymidylate synthetase. Analyt. Biochem. 17, 553556.

Krishnakumaran A., Berry S. J., Oberlander H., and Schneiderman H. A. (1967) Nucleic acid synthesis during insect development. II-Control of DNA synthesis in the Cecropia silkworm and other Saturniid moths. F. Insect Physiol. 13, 1-57.

Lomax M. I. S. and Grebenberg G. R. (1967) A new assay of thymidylate synthetase activity based on release of tritium from deoxyuridylate-5- ${ }^{3} \mathrm{H}$. \%. biol. Chem. 242, 109-113.

LoRENSON M. Y., MALEY G. F., and MALEY F. (1967) The purification and properties of thymidylate synthetase from chick embryo extracts. F. biol. Chem. 242, 3332-3344.

Lowry O. H., Rosebrough N. J., Farr A. L., and Randall R. J. (1951) Protein measurement with the Folin phenol reagent. F. biol. Chem. 193, 265-275.

MALEY G. F. and MALEY F. (1959) Nucleotide interconversions in embryonic and neoplastic tissues- - . The conversion of deoxycytidylic acid to deoxyuridylic acid and thymidylic acid. F. biol. Chem. 234, 2975-2986.

Mathews C. K. and CoHEN S. S. (1963) Inhibition of phage-induced thymidylate synthetase by 5-fluorodeoxyuridylate. F. biol. Chem. 238, 367-370.

ReYes P. and HeIDELBERger C. (1965) Fluorinated pyrimidines-XXVI. Mammalian thymidylate synthetase: its mechanism of action and inhibition by fluorinated nucleotides. Mol. Pharmacol. 1, 14-30.

Ritossa F. M., Atwood K. C., and Spiegrlman S. (1966) A molecular explanation of the bobbed mutants of Drosophila as partial deficiences of 'ribosomal' DNA. Genetics 54, 819-834.

Rizki T. M. (1968) Site of incorporation of 5-fluorouracil in Drosophila. Genetics 60, 215.

Rızki R. M. and Rizki T. M. (1969) Somatic cell lesions induced by the base analog 5-bromodeoxyuridine. Cancer Res. 29, 201-208.

RIzkI R. M. and RIzKI T. M. (1972) Morphogenic effects of halogenated thymidine analogs on Drosophila-III. 5-Iododeoxyuridine. Experientia 28, 329-332.

Rizki R. M. and Rizki T. M. (1973) The role of thymidylate synthetase inhibitors in bromodeoxyuridine-induced neoplasia in Drosophila. Cancer Res. 33, 2856-2861.

Rizki T. M., Rizki R. M., and Douthit H. A. (1972) Morphogenic effects of halogenated thymidine analogues on Drosophila-I. Quantitative analysis of lesions induced by 5-bromodeoxyuridine and 5-fluorouracil. Biochem. Gen. 6, 83-97.

Williams C. M. (1965) DNA synthesis and hormonal control of insect metamorphosis. Science, Wash. 148, 670. 